This is a self-archived version of an original article. This version may differ from the original in pagination and typographic details.

Author(s): Wang, Shuchen

Title: Turning Right/Turning Left? : A Neoclassical Socioeconomic Query of the Arts Signaled by Museum and Branding in Finland

Year: 2016

Version: Accepted version (Final draft)

Copyright: (c) 2016 Taylor \& Francis

Rights: CC BY-NC 4.0

Rights url: https://creativecommons.org/licenses/by-nc/4.0/

Please cite the original version:

Wang, S. (2016). Turning Right/Turning Left? : A Neoclassical Socioeconomic Query of the Arts Signaled by Museum and Branding in Finland. Journal of Arts Management, Law, and Society, 46(4), 164-176. https://doi.org/10.1080/10632921.2016.1209142 


\title{
Turning Right / Turning Left? \\ A Neoclassical Socioeconomic Query of the Arts Signaled by \\ Museum and Branding in Finland
}

\author{
Shuchen Wang \\ Jyväskylä Univeristy, Finland
}

\begin{abstract}
Guggenheim Helsinki Plan indicated a wishful turn of the arts and culture in Finland from the socio-democratic tradition of a welfare society towards a further neoliberalism. Following the Finnish historical timeline and from a museological viewpoint, this paper reviews how national identify was built through the arts, which later integrated into formal and informal education to enhance human capital. This instrumental view now promotes the idea of useful art to fuel innovation economy of advanced technology. Considering embarking the intricate platform of arts, economics, and finance through Guggenheim, rethinking contemporary art market mechanism may prove to be beneficial.
\end{abstract}

KEYWORD: Museology, Art Hisotry, Arts Management, Cultural Identiy, Branding, Cultural Economy, Art Education, Cultural Policy, Neoliberalism, Art Market

\section{INTRODUCTION}

Art is highly appreciated by all human societies. Bio-anthropologist even considers it an important feature of our humanity, and it is a must-have subject to almost all philosophers. However this paper does not discuss arts from these perspectives but within a historical and sociological context, in terms of Finland, a one hundred years old country, the most American country in Europe, so they said. With Guggenheim Helsinki Plan as prelude, this study is about the role of arts played for, by, and in this country. National history, cultural heritage, art education, and cultural policy are various elements that this paper composes its discourse. Through literature review and analyzing digital archives of relevant arts organizations, it becomes clear that coined with a socio-democratic political tradition and mix economy system since the sixtieth art has played an instrumental role in this Finnish tradition: from building nation-state and cultural identity to enhancing "human capital" in formal and informal education, from generating creative economy and cultural industry to fueling up innovation economy of advanced digital technology.

It is difficult to judge this tended socioeconomic turn towards further neoliberalism signaled by Guggenheim Helsinki Plan. Looking into the past and reviewing those steps that led us to where we are today, is perhaps a good method to find reference. In order to have an overall picture about the 
arts and cultural development of this country since the time when its independence was conceived, the first part is to reconstruct the national history with the viewpoint that its national identity was built though the arts. It was under an urge of romantic nationalism that material and immaterial cultural heritage was gathered and institutionalized around the late nineteenth and early twentieth century to forge a cultural identity supporting political request of independency. The lack of the material cultural heritage made the immaterial one imperative, notably documentation of back-then still live oral tradition. Although the absence of monarchy had made this country rather fair and equal in social structure, in museological development this also resulted in weak high art and high culture, that often became the basis of modern museum institution. Instead of cabinet of curiosity or royal art collection, existed here only artworks created and owned by various arts societies and their founding members, in music, drawing, and writing. Under this specific historical light, the value of art (collection) was invented with passionate nationalism since the vey beginning and that later was integrated and performed in the country's formal and informal education system. Now after another turn of the century, arts start to be seen as with added value along free-market capitalist mechanism, as artistic creativity is expected to fuse into technological innovation. "Useful art" is then being promoted to boost innovation technology economics. If Robin Hood project represents a romantic attempt to conciliate arts and finance by a local art community, Guggenheim Helsinki Plan represents then the governmental intention to install Finland into international contemporary art landscape meanwhile seeking tangible return of investment.

\section{GUGGENHEIM CHALLENGES HELSINKI}

On the north-eastern shore of the Baltic Sea a "twenty-first century art museum" (Durry et al. ed. 2011, 4) was envisioned right after the first decade of the new millennium by a few local politicians, as often the case, and a global-scaled international art enterprise-the Solomon R. Guggenheim Foundation (SRGF), which sought to create another branch following its success stories outside the USA in Venice, Bilbao, Berlin (1997-2013), and AbuDhabi (SRGF 2015) as well as some failed ones, often accompanied with certain financial or political scandals, in countries like Austria (Fowler 1990), Brazil (Kaufman and Verlichak 2002), Mexico (Artdaily 2005), Taiwan (Pollard 2003), China (Reuters 2007), and Lithuania (Etherington 2008). To Helsinki, the first proposal was presented in 2011 and rejected by the city council in 2012; and in 2013 a revised version was submitted again with certain modifications: stand alone from the city art museum, lower annual operation cost, higher revenue prospection, focus on the theme of Nordic architecture and design, build a permanent art collection, and solicit licensing fee from private sponsors instead of public funding (Moser et al. ed. 2013). In 2014 the city council agreed to reserve a museum site in its renewal urban plan around the 
Southern Harbour and an international architecture competition was open and accomplished around mid-2015. Although again being under consideration by the city council, debates over the Plan between opponents and proponents are still scorching.

With the common public staying mostly neutral, arguments over this Guggenheim Helsinki Plan are mainly from the arts sector and the political circle. The former includes museum director and curator, minister of culture, art critic, and artist with main concern about SRGF's projected visitor number, optimistic impact on tourism, and most important of all, their already thinned government subsidies being diluted even more (Siitari 2012). The latter contains mainly city mayor, prime minister, minister of economic affairs, minister of defence, and private gallerist with expectation on Finland's international media exposure rate, economic opportunity, strengthening Helsinki's cultural status, and bridging local artist unto international venue through SRGF (Sullström 2012).

To buy or not to buy the Guggenheim brand? Answer theoretically may depend on how this deal would influence Finland's creative economy, cultural industry, global contemporary art landscape, local artist and art institute. Apart from those opmistic statistic numbers given by an international business management and consulting agency, it is perhaps beneficial if the search of possible answer and the reasoning would go further than superficial calculation and dive into historical background, value of the arts in Finnish national identity, culture, and education along this country's centenary history. Following the development of Finnish cultural policy history, Guggenheim Helsinki Plan might be a significant sign indicating a socioeconomic turn from a welfare society with socio-democratic tradition to joining the free-market spirited neoliberal capitalist economic system. It is then understandable under this light that why current Finnish political liberals are against the Plan and conservatives are for it (Wainwright 2014).

\section{LOOKING BACK: INDEPENDENCE, NATIONALISM, AND THE ARTS}

The almost faute de mieux independence according to Jakobsson (Volner 2015, Lavery 2006, 92) from the tsar in 1917 has made the national history of Finland peculiar from its neighboring countries but close to those ones independent from the fall of Russian and Austro-Hungarian empires at the end of the First World War. The long history from 1157 to 1809 under the Swedish Crown being a part of the Kingdom of Sweden had established a rather stable social structure composed mainly by four social classes: the nobility, clergy, urban burghers, and peasantry. During this Swedish era, Finland evolved identically with other parts of the Kingdom, in religion, political institution, culture, and economy, except language-an oral language without written form spoken only by the Finns with linguistic link to Uralic rather than Norse. Before the early modern time whereas nation emerged as a conceptual entity that people were primarily loyal to, Finland had existed 
more in a geographical sense rather than ethnic or cultural. Being remote from the power center like Roman Catholic Church or Swedish court, the majority of local population belonged to the lowest social class, peasantry (higher classes were mostly composed by Swedish immigrants). This ninetyfive per cent local habitants, though presented in the parliament and could own their lands and were free to move (William 1974), had to bear ninety per cent of tax coming from the farmlands where they were regulated to live in. The way of living as small independent peasants over hundreds of years might have left traits in certain collective cultural characteristics such as solitude, realism, and modesty (Lewis 2005). It morever had prevented wealthy cities to emerge as labored products and recourses were gathered and removed away from Finland and the sparsely distrubited farmer residences made it didfficult to form or organize any opinion center against the empirial domination from Stockholm (Lavery 2006, 34).

Located in the transit of Eurasia, this land of Finns was constantly devastated by warfare between Swedish Crown and Novgorod along the eighteenth century. However, it was also because of this power struggle from both sides that made space for the seeds of a Finnish nation-state to grow. Vis-à-vis Russian invasion Finland was treated more and more as a separate place by Stockholm for economic and military needs. Another contributing factor was the influence of some liberal economists from continental Europe to promote free trade that inspired certain social reforms to liberate regulations and special privileges (Lavery 2006, 44). Thus in 1809 when Sweden signed the treaty with the Russian Empire, Finland earned its autonomy as a grand duchy. Since then, tax was allowed to be kept in this land and the Russian Empire facilitated the advance of Finland's political organization, nationhood, economy, and civil society, until the turn of the twentieth century.

Under the turmoil sociopolitical circumstance during the eighteenth century, some Finns started to seek alternative political alignment in exchange for peace. In 1788 some officers out of the feeling that Sweden regarded Finland simply as a military stage, wrote a letter to Russia expressing a desire of peace. Around 1780s Sprengtporten (1740-1819) drew a plan of an independent Finland that influenced greatly the court of Russia in the nineteenth century. These actions were accompanied by an ever-growing sense of "Finnish-ness". In defining it, Juslenius (1676-1752) even fanaticized that finnic culture was connected to Greek and Hebrew and there had been a great prehistoric Finnish civilization. On the other hand, Porthan (1739-1804) tried to anchor this lost great civilization from folklore and to further consolidate Finnish ethnicity by language, he established the Aurora Society to promote local culture and published the first local newspaper in Swedish.

This intellectual movement continued and grew even stronger into the second half of the nineteenth century after the Crimean War in the 1850s. 
Nourished by the Enlightenment and the Romanticism, those upper class Swedish-speaking elites studied overseas in continental Europe or belonged to Stockholm intellectual circle, started to forge a romantic nationalism through a Fennomanic movement. Of which the motto was "Swedes we are no more, Russians we cannot become, therefore Finns we must be (Kinge ed. 2003)". This eventually established Finnish language and finnic culture predominant, from peasant status to the leading position of a national language and culture, when the grand duchy of Finland found itself suddenly without the tsar being its duke in 1917 and left independent. Different from countries like Norway who won independency from (Swedish) foreign rule or Germany who united into one based on linguistic, cultural, and ethnic ground (Smith 1995, Thomasett 1997), those Swedish-speaking elites in Finland of the nineteenth century who tried to build up a "national identity" from Russia could not share the same grounds, because linguistically or ethnically speaking they were not Finnish. Therefore, in art making, they sought to create a collective identity artistically, culturally and politically of painting, music, architecture, and literature-some Swedish writers thence started to write also in Finnish.

\section{CULTURAL POLICY ON MUSEUM FOR NATION BUILING}

Traditionally, collection forms the base of museum foundation and serves as the starting point of relevant knowledge building and dissemination. This has been made explicit in the development of European museum history: from Alexander's garden in Antiquity, Middle Ages church treasure, royal art collection after Renaissance and cabinet of curiosity during the Enlightenment Era, until modern museum opened to the public after the French Revolution (Schaer 1993). Also revealed here is the close tie between museum collection and certain concentrated socioeconomic power along different epoch. The above-mentioned historical background of Finland becoming a nation-state in 1917 has hinted a museum culture and history rather exceptional as it was almost non-existent the so-called high art and high culture as material evidence to form any classical museum collection, as often seen elsewhere in Europe.

Peasantry seemingly did not achieve or leave much tangible cultural heritage preserved as archaeological finds, historical monuments, or refined artefacts. There were only twenty sites reported to the Antiquities College in Stockholm by the appointed clergy in late seventeenth century (NBA 2015). Besides, those few church heritages were found small and humble though could be dated back to the medieval time. Furthermore there was not any part of royal art collection or cabinet of curiosity kept here locally from Stockholm or St. Petersburg, and very few private art collections bought by those newlyrich during the time of industrialization were left. Therefore when thriving to forge a sense of nationalism against the tsar's russification (Thaden 1981), those Swedish-speaking elites could not but find works of art made by 
themselves, their peers or students during the nineteenth century as material support.

This bottom-up way of cultural identity construction-by assembling contemporaneous material objects to compose a collective memory and identity in Finland-actually resonates the idea of "new museology" about one hundred years later in France. In any case, several knowledge societies were established by these Fennomanic elites, and relevant collections were accumulated underneath that later on became actual contents of Finnish museum institutes. E.g. the 1870 Finnish Antiquarian Society's documentation of historical monuments became the content of National Museum of Finland under the administration of the National Board of Antiquity (NBA 2015); the 1846 Finnish Art Society's collection became basis of the National Gallery including Ateneum Museum and Kiasma Contemporary Art Museum (Ateneum 2015); the 1821 Societas Pro Fauna et Flora Fennica donated part of its collection to the 1924 National Museum of Natural History integrated into the University of Helsinki (Skyten 2015); and the 1831 Finnish Literature Society (Saturday Society) holds the biggest oral history collection in the world still today.

Characteristics or results of this museum rush responding to specific sociopolitical request in using arts and culture to brand a nation-state's identity as cultural policy, are that: 1) museum quantiy surpasses quality; 2) all museums are supported by public funding, either central or municipal, fully or partially; 3) only one third (Goodnow \& Akman ed. 2008) are run by professionals; 4) most are open seasonally, half day, few days a week, or by appointment; 5) typical functions as collection, research, exhibition, and education (Alexander 1979) are performed separately by a single institute or collectively by a nexus of certain museums. Besides, as architecture is a potent instrument and token expressing sentiment of nationalism (Giebelhausen ed. 2003, Gervits 2012, Quek et al. ed. 2012), Finland complied as well to this trend at the turn from the nineteenth to the twentieth century by building up several museums buildings with the so-called "Finnish characteristics" (Asyby 2012, Kansallisgalleria).

Also worth noticing is that the "nationalization" of those collections owned by various intellectual societies took a very long time. E.g. The ownership over the art collection held by the Finnish Art Society was transferred to the State, staying at where they were stored and displayed in Ateneum Museum, only in 1990 (Levanto 1987). Apart from the collection, the transformation or expansion of these organizations can reveal a social history of Finnish arts and culture. Very often, those societies established by the Swedish-speaking elites would continue to exist after transferring some of their main tasks or collections to another organizations (often Finnishspeaking) founded later, with original founding members and minor tasks left. The Finnish Art Society is a good example, versus the Finnish Academy of Art 
Foundation founded in 1939 taking over its collection and role of art education. This sociocultural divide between Finnsih and Swedish communities was rooted since the birth of the country, and became an invisible line that expanded all the way from arts and culture to economic and political landscape. It is not too much to say that although it was the Swedish-speaking group took the initiative to forge a sense of nationalism, culturally and politically and started to educate then often-being-oppressed Finnish community, it seems natural today that younger generations of the latter would take over the power of decision making after being educated as they anyhow outnumbered the former being the majority of the coutnry's population. First complaints of Finnish-speaking artists towards those Swedish-speaking founders and members of those societies, such as GallenKallela (Pettersson 2015), were heard in the thirtieth concerning justice in arts competition and grant issue, about one generation away from the nation's formation in 1917. Today, the only service language of the "national collection" online system is Finnish. This power transition with political sensitiveness somehow went unspoken in terms of the country's cultural policy design and implementation.

As said, this cultural divide within the nation-state of Finland was embedded as early as the Fennomanic movement took its initiation. Back then, those Swedish-speaking elites, if not moving back to their motherland, as Jacob Frese and Frans Mikael Franzén, had maintained very close relations with the intellectual circle of Sweden, e.g. the Turku Romantics stood ideologically close to the Uppsala Phosphorists (Zuck 2015). Promoting a romantic nationalism not based on their language or ethnicity but on geographical sense and a rather "aboriginal" culture, these Finnicized Swedish-speaking elites might not have expected to be challenged later on and needed to give away their authoritative power in the arts and cultural scene. Encompassed with economic reason, since the thirtieth a steady migration of the Swedish-speaking Finns back to Sweden has started and it somehow continued until now (Westerholm 2002).

\section{INSTRUMENTAL ARTS EDUCATION}

Art education, being constantly redefined with its cross-disciplinary nature and enlarging content along technology advancement, plays an important role in achieving Finland's renowned success in education. Bresler (2007) noted the trendy phenomenon to replace "art education" with "arts education" indicating that all art genres as music, visual art, drama, and dance tend to be put under the umbrella of "the arts". The thirteen subjects of the colossal handbook Bresler edited has well described current development of art education relevant studies in Finland: history, curriculum, assessment and evaluation, composition, appreciation, museum and cultural centers, informal learning, child culture, social and cultural issues, the body, creativity, technology, and spirituality. In the article "Capitalizing art education: mapping 
international histories" Stankiewicz suggested a possible way to describe various stage of arts education: from prehistory to Renaissance, elite's amateur liberal art education during national formation 1600-1800, capitalism and middle-class aspirations 1800-1850, industrial impact 1850-1910, ideology of child artist 1910-1960, and intellectual rigor 1960 until now (Bresler 2007, 7). Although this periodization is not universally valid with a sole focus on the English-speaking area, it somehow reflects a partial truth in terms of Finland, notably the amateur art education of those Swedish-speaking elites around the late nineteenth and early twentieth century, whereas started officially the first chapter of Finnish art history, cultural history, literature history, and arts education history.

As described above, the arts and culture bearing "Finnish features" did not exist until those Fennomanic Swedish-speaking elites thrived to construct a romantic Finnish nationalism. In the beginning, there was nothing. Not only they could not find material evidence of cultural heritage to support their ideation of a nation, they also realized that the practice and knowledge of art making were practically void. It was from continental Europe they brought back this art-making convention and set up those societies. However, their European models were set originally to express artists' discontent towards goods of mass production from industrialization, here these Finnish copies were nevertheless found standing alone in a soil without any arts tradition, as Zachris Topelius had exaggerated with his synical remark "visual art in Finland were to be found only on curtains and wallpapers" (Petterson 2015).

Therefore, the primary missions of these arts societies were to cultivate Finnish art maker and audience, in another words, to invent the Finnish art world from scratch. Apart from Helsinki Music Institute in 1882 starting music education, Finnish Literature Society in 1831 has further established Finnish as a literary language instead of continuing the Swedish literature tradition, and then Finnish Artist Society in 1846 created the visual art scene completely, from teaching art to founding museum collection and from organizing raffle to holding exhibition.

It was under these semi-private and semi official institutionalized efforts that the arts started to grow in Finland. Four years after the establishment, Finnish Artist Society opened its Drawing School in 1848 and started purchasing artworks as teaching models in addition to those donated ones by its board members. This School educated the first "Finnish artists", e.g. Albert Edelfelt, Axel Gallen, Helene Schjerfbeck, and Ellen Thesleff (uniarts.fi). Their works were said to have strong "Finnish features" and some of them were collected by the Society and became "national collection" later on. This development not only reflects a primitive cultural policy rooted in intellectual, nationalism, and the arts as Sokka and Kangas (2007) claimed, but also indicates the strong instrumental view on the arts from this cradle time of Finnish arts education. Based on a socio-historical perspective, Sokka (2007) 
further argues that arts and culture can be a "realized signifying system" of public cultural policy engaged with contingency of human action and public nature of political action. It is clear that "I'art pour l'art (art for art's sake)" as a matured philosophical thinking of art in the early nineteenth century France did not reach Finland, especially with those soieties' founding members and later art educators preoccupied in building up a nation-state with a romantic nationalist sentiment seeded, embodied, and performed in their and their students' artworks. This nationalist characteristic of art making and art education, has been integrated into formal education curriculum and informal education system right away when the nation came into being, and has continued over the twentieth century until today.

Although little studied still, some scholars have suggested that arts education has contributed to the overall success of Finnish education, which is renowned worldwide (Baker 2012, Hancock 2011, Rubin 2012). The country's minister of education said in an interview in 2014:

Regardless of a person's gender, background, or social welfare status, everyone should have an equal chance to make the most of their skills. It's important because we are raising the potential of the entire human capital in Finland. (Gross-Loh 2014)

This claim has well illustrated the instrumental viewpoint on education with the arts involved, as she went on saying in the same interview that why hands-on creative activities compose important part of classrooms is because pupils "benefit more from handcrafts, cooking, creative pursuits, and sports". Garber (2002) as well concluded the reasons to keep arts education robust in schools are:

1) cognitive development in several dimensions, 2) learning about the living world, 3) Finnish traditions and culture, 4) school and individual growth, and 5) a break from the demands of academic subjects.

Although the policy analysis reports on arts education and cultural education (2010) shows that in terms of primary schools the teaching hours of the arts has largely decreased from 1985 to 1993, and again decreased since 2001, the arts education activities have been increased in the informal education system since the 1980s (Heinimaa 2015). A document from the association of Finnish arts education for youngsters entitled "Basic education of art, media, architecture and design to children and young people" shows that local authorities providing basic arts education receives statutory government transfers, and all public and private arts education providers can acquire government grants. Besides, in constructing a history of cultural policy in Finland Sokka and Kangas (2007) divide the historical timeline into three 
periods: 1) nation building 1860-1960, 2) the welfare state 1960-90, and 3) competitiveness society 1990-now. This viewpoint again confirms the instrumental role the arts and culture played in Finland's history. The arts education firstly serves nationalism in the aim of creating an independent nation-state from the tsar. Then it became a tool to cultivate best "human capital" when establishing the country's welfare system spirited with an education philosophy in equality, non-competitiveness, collaboration, free education, individual right of teacher and student, and so on. Now the turn towards neoliberalism has become a hot topic in many post-welfare societies. Finland as well, is trying to re-define the role of arts and culture for the $21^{\text {st }}$ century embracing the third industrial revolution and global economy.

\section{NEW DIRECTION OF THE ARTS}

As known, the political concept of "left" and "right" has been evolved since these terms firstly appeared during the French Revolution in 1789. Today a spectrum from the left, the central to the right is often used to depict various political position, ideology, and party. In fact, the "right" supported by the Old Finn Party, the Swedish People's Party, and other non-Socialist parties had once won over the "left" at the dawn of Finland's independence. However, the abdication of the German prince Friedrich Karl to assume the Finnish throne had made space for the "left" composed by the Agrarian League, the Social Democrats, and the Progressives to win the absolute majority in parliament in 1919 and decided Finland as a republican rather than monarchy. Different from political settings, the Finnish economic structure was traditionally with characteristics not very "right" although Finland is considered "the most American country in Europe" before the European Union came into being (Lavery 2006, 14). Although greeted the liberalist by the 1860 s and welcomed the neo-liberalist during the 1990s, Finland, just like other Northern countries held a mix economy with welfare social structure.

Arts and culture under this socioeconomic system, has a functional role in strengthening national identity and increasing quality education, as discussed above, as well as in enhancing social wellbeing (Liikkanen 2010, Brandenburg 2009). Artworks are therefore seldom considered as commodity but means of self-expression, mental health, and emotional comfort (Ruismäki \& Ruokonen ed. 2011). Besides, comparatively abundant funding opportunities, fair fiscal structure, and strong social welfare system contribute to provide artists a rather stable though moderate financial life if opting to be self-employed independent art professionals. Notwithstanding, a recent anthology edited by Triisberg, Krikortz, and Henriksoon entitled "Art workers, material conditions and labour struggles in contemporary art practice" (2015) through a collaboration among artists from Finland, Sweden, and Estonia has summarized a collective sentiment of dissatisfaction about the material compensation of their works. This hardened situation for artists is actually a reflection of the economic recession. 
The deep recession in 1990s has provoked cultural policy makers in Finland to have critical view on governmental administration and intervention of mix economic welfare system and to start to consider possible alternatives. The economic crisis around 2007 again has reinforced the will to make change with pro-Thatcherism attitude. The following statement of a national project named Creative Industries Finland 2007-2013 has well declared this move.

The development of business activity within the creative industries is being promoted in response to the structural reform related to production and the economy. This has seen the focus of production shift from the material to the immaterial. Such a change requires new types of competence. This is the message of the development programme for business growth and internationalisation in the creative industries. (Rakennerahastot.fi)

Thence arts and culture are expected to generate tangible value. This turn is followed by further conception that artistic creativity should be fused into innovation economy of advanced science and technology. Hautamäki's article "Creative economy and culture at the heart of innovation policy" (Minedu 2010) quoted Landry's concept of bridging culture to creativity through "hard" and "soft" infrastructures in suggesting that arts and culture can be an inspiration for creativity, which is essential to innovation economy. He specifically mentioned here the Guggenheim Bilbao example. This further turn also demonstrates itself in the re-organization of cultural heritage institutes. The Finnish National Gallery became an independent public foundation in 2014 with a promise to enable stronger online presence of its collections (Kansallisgalleria.fi). Although not yet declared a concrete future working plan, this organizational transformation has strengthened the mobility and efficiency of the network of its subordinating three museums (Ateneum, Kiasma, and Sinebrychoff) with successful international tour exhibitions and highest records of exhibition visits. It is the American model of "foundation managed museum institute" that this new operation model is looking up to. The notable example is of course, the Guggenheim, which employs cutting-edge media technology to communicate, promote, and maximize for example its copyright economy, to name just but one, among its many other successful global arts business.

\section{CONCLUSION AND DISCUSSION}

Analyzing the historical context from various perspectives, it became clear why appeared the Guggenheim Helsinki Plan and politicians supported it. The greatest expectation from the government's perspective is perhaps to prosper Finland's creative economy and cultural industry through this museum brand and its global venues. However, the majority of art workers seemed not trusting it. However difficult it is to predict the future, hints and 
insights might be discovered looking into the past and that is the rationale of this paper. Besides, a few issues might be worth considering amidst this turn in the arts and culture from socio-democratic tradition towards neo-liberalism. E.g. Contemporary art market mechanism and its socioeconomic context, the evolvement of art's value from intangible to tangible might involve structural variance between different societies, and the challenge of "human capital" facing "social capital", a concept being promoted by Portman (2013) in providing solution to the crisis of "American dream".

As a matter of fact, the relationship between arts and economics has become a heated subject since recent years, viewing the prosperous scenery painted by commercial gallery, art fair, biennale, auction, art collector, private and public foundation, art investment, star-artist, critic, museum, art center, and so on. Finland stays quite far from this glamorous world. Remembering that it was starting from scratch those Swedish-speaking elites had built up the Finnish art world. Completely upon their personal effort, they could not but had to be content with copies instead of original works from those European art masters. Nor could they envision building up at the same time a similar convention of art market as in Netherland and Britain starting from the seventeenth century (Houdt 1999, Zablotney 1999). Prior to this time, in continental Europe art itself with various form, medium, style, and value as well as the professionalization and classification of artist had gone through a long journey with many times socioeconomic change, whereas arts' patron, sponsor or consumer have shifted from or renewed by church authority, royal court, newly-rich middle class, to the common public (Lenman 1997). It is America that shared similar arts reality with Finland. Barber's article "International Art Deal and American Economic Politics 1789-1913" (1999) in discussing the early history about taxation over imported artworks from Europe has not only revealed how the tax exempt system has been founded but also mentioned the liberalist attitude towards arts education. Also starting from scratch, different from Finland who followed the continental European tradition that governments are active sponsors in art school, museum, and artist, America adopted an liberal attitude right from the start: to cancel protectionism towards domestic artist, to purchase quality artworks from Europe with tax exempt, and to participate international art market. Barber assumes both protectionist and liberalist held the same acknowledgement: America was left very far behind other countries in arts and culture. Some thought that local artist and audience needed this stimulation from seeing freely circulated first-class artworks to catch up, and it was commonly believed that it was hopeless that America could catch up one day (Barber 1999, 230). However, this American model may have proved to be successful. New York anyhow replaced Paris after the Second World War and became the world's art capital, with important players like the Guggenheim. 
The dark side of this seemingly positive result of the American model is that art market often is flooded with dishonest operation, money laundry, and art crime (Robertson ed. 2006). When the value of art becomes straightforwardly tangible, art the visual, becomes a conceptualized item with a price that can be operated as in any stock market. Current contemporary art world is full of this kind of stories, especially with the latest market starChinese contemporary art. It is almost impossible for outsiders to catch clues about the intricate contemporary art market mechanism. For instance, it triggers curiosity the relationships among various Guggenheim related organizations: Guggenheim Foundation, Guggenheim Museum(s), Guggenheim Investments, Guggenheim Partners, etc. Besides, the contribution of arts education to increase "human capital" has been proven successful in Finland, and the free-market neoliberalism in the USA has created the crisis of "American dream" and scholars like Putnam has suggested to increase "social capital" following the welfare system of northern countries as a remedy. Should Finland embrace now this American model of neoliberalism using Guggenheim Helsinki Plan as a springboard?

The small-scaled experimental project of art and finance "Robin Hood" (Robinhoodcoop.org) might provide interesting insights. With a dynamic datamining algorithm that follows US stock markets and acts along, the benefits contribute to a commons and would fund selected public art projects. The game is rather simple, yet the primitive way of bridging arts and finance is thought provoking. As values of stock and art become self-exchangeable and can nourish each other. Perhaps it does not matter eventually which path we choose, right or left. Unlike Robert Frost's two roads diverged in a yellow woods, our two roads (or many roads) in the arts and culture will meet eventually at the same end, as a splendid imprint of humanity, just like those fascinating paintings inside the caves of rock art. What is important is the life choice of every individual, artist or art audience. To consume art as luxury product or to approach it as spiritual activity, this cannot be determined by any design of socioeconomic mechanism.

\section{REFERENCE}

Alexander E.P. 1979. Museum in Motion. Nashville: American Association for State and Local History.

Artdaily. 2005. "Enrique Norten Will Design Guggenheim in Guadalajara." Artdaily.org. http://artdaily.com/news/13913/Enrique-Norten-Will-Design-Guggenheim-inGuadalajara\#.VoK23TZQVSU (Retrieved 1.7.2015)

Ashby C. 2012. The Pohjola Building: Reconciling Contradictions in Finnish Architecture Around 1900. Quek et. al. ed. Nationalism and Architecture. Pp 135-146. .11.2015)

Ateneum. 2015. The history of the Ateneum Art Museum and its collections. Ateneum Museum. http://www.ateneum.fi/en/history (Retrieved 1.11.2015)

Baker C.R. 2012. What we can learn from Finland's education system. Deseret News. http://www.deseretnews.com/article/865563989/What-we-can-learn-from-Finlandseducation-system.html?pg=all (Retrieved 1 
Barber W.J. 1999. International Art Deal and American Economic Politics 1789-1913. Marchi

N.D. and Goodwin C.D.W. Ed. Economic Engagements with Art. Duke University Press.

Brandenburg C. 2009. Art, health promotion and well-being at work. http://arted.uiah.fi/synnyt/1 2009/brandenburg.pdf (Retrieved 1.11.2015)

Bresler L Ed. 2007. International Handbook of Research in Arts Education. London: Springer.

Etherington R. 2008. "Guggenheim Hermitage Museum, Vilnius by Zaha Hadid Architects." http://www.dezeen.com/2008/04/10/guggenheim-hermitage-museum-vilnius-by-zahahadid-architects/ (Retrieved 3.7.2015)

Fewster D. 2006. Doctoral dissertation: Visions of Past Glory: Nationalism and the Construction of Early Finnish History. Helsinki: University of Helsinki.

Fowler B. 1990. "Salzburg Guggenheim Offshoot Exists in Hopes and Blueprints." http://www.nytimes.com/1990/08/13/arts/salzburg-guggenheim-offshoot-exists-inhopes-and-blueprints.html (Retrieved 4.7.2015)

Garber E. 2002. Craft Education in Finland: Definitions, Rationales and the Future International Journal of Art \& Design Education. Volume 21, Issue 2, pages 132-145.

Gervits M. 2011. Historicism, Nationalism, and Museum Architecture in Russia from the Nineteenth to the Turn of the Twentieth Century. Visual Resources Volume 27, Issue 1, 2011.

Giebelhausen M. Ed. 2003. The architecture of the museum, Symbolic structures, urban contexts. Manchester and New York: Manchester University Press.

Goodnow K.J. and Akman H. Ed. 2008. Scandinavian Museums and Cultural Diversity. P.107.

Gross-Loh C. 2014. Finnish Education Chief: 'We Created a School System bAsed on Equality'. In interview with the country's minister of education, Krista Kiuru. http://www.theatlantic.com/education/archive/2014/03/finnish-education-chief-wecreated-a-school-system-based-on-equality/284427/ (Retrieved 1.11.2015)

Hancock L. 2011. Why are Finland's schools successful? The country's achievement in education have other nations, especially the United States, doing their homework. Smithsonian magazine. http://www.smithsonianmag.com/innovation/why-are-finlandsschools-successful-49859555/?page $=2$ (Retrieved 1.11.2015)

Hautamäki A. 2010. Creative economy and culture at the heart of innovation policy. Creative Economy and Culture in the Innovation Policy. Helsinki: Ministry of Education, Department for Culture, Sport and Youth Policy.

Heinimaa E. 2015. From art school to basic education of art. Suomen Lasten Ja Nuorten Kuvataidekoulujen Liito RY. http://youngart.fi/in-english/from-art-school-to-basiceducation-of-art/ (Retrieved 1.11.2015)

Houdt T.V. 1999. Art Economics of Early Modern Era. Marchi N.D. and Goodwin C.D.W. Ed. Economic Engagements with Art. Duke University Press.

Kansallisgalleria. 2015. http://www.kansallisgalleria.fi/en/ajankohtaista/ (Retrieved 1.11.2015)

Kansallismuseo. 2015. History of the Natinoal Museum and the museum building. http://www.kansallismuseo.fi/en/nationalmuseum/history-of-museum-and-building (Retrieved 1.11.2015)

Kaufman J.E. and Verlichak V. 2003. "Guggenheim goes to Brazil." Forum Permanente. http://www.forumpermanente.org/administ/arquivo hibernante/guggenheim/gugg bra zil (Retrieved 2.8.2015)

Klinge M. Ed. 2003. Suomen Kansallisbiografia 1. Helsinki: SKS. P. 406.

Lavery J. 2006. The history of Finland. Westport: Greenwood Press.

Lenman R. 1997. Artists and society in Germany 1850-1914. Manchester and New York: Manchester University Press.

Lewis R.D. 2005. Finland, Cultural Lone Wolf. pp53-65. London: Nicholas Brealey Publishing. Levanto M. 1987. Ateneum Opas. Helsinki: Otava.

Liikanen H.L. 2010. Art and Cutlure for Well-being; proposal for an action programme 20102014. Helsinki: Ministry of Education 
Minedu. 2010. Arts Educatio and Cultural Education in Finland. Policy Analysis Reports of the Ministry of Education and Culture. ISSN 1799-0394

Moser K., Byers H., Goldhar E., Kingsley L.L., Vaz T., and Wiseman A. Ed. 2013. Guggenheim Helsinki Revised Proposal. New York: Guggenheim Museum Publications.

NBA. 2015. The history of antiquities administration in Finland. National Board of Antiquities. http://www.nba.fi/en/about us/history (Retrieved 1.11.2015)

Museoliitto. 2015. Finland's Museum History—collecting, researching and educating. Museoliitto. http://www.museoliitto.fi/museumhistory (Retrieved 1.11.2015)

Pettersson S. (2015). Becoming number one player in art. Finnish Art Society.

Pollard B. 2003. "Guggenheim may open in Taiwan." BBC News. http://news.bbc.co.uk/2/hi/entertainment/3072383.stm (Retrieved 1.7.2015)

Putnam R.D. 2013. Our Kid, the American dream in crisis. New York: Simon \& Schuster

Quek R., Deane D., Butler S. ed. 2012. Nationalism and Architecture. England: Ashgate Publishing Limited.

Rakennerahastot. 2015 From a creative economy to sustainable growth and welfare. Rakennerahastot.fi

Reuters. 2007. "Guggenheim mulls museum project in Beijing." Reuters. http://www.reuters.com/article/us-china-guggenheim-idUSPEK21787020070209 (Retrieved 1.7.2015)

Robertson I. ed. 2006. Understanding International Art Markets and Management. New York: Routledge.

Rubin C.M. 2012. The global search for education: the arts face to face. Huffington Post, Education. http://www.huffingtonpost.com/c-m-rubin/the-global-search-foredu 30 b 1308386.html (Retrieved 1.11.2015)

Ruismäki H. and Ruokonen I. Ed. 2011. Arts and Skills-Source of Well-being, Third International Journal of Intercultural Arts Education. Helsinki: Helsinki University

Drury T., Byers H., Kingsley L.L. and Wiseman A. Ed. 2011. Concept and Development Study for a Guggenheim Helsinki. New York: Guggenheim Museum Publications.

Schaer R. 1993. L'Invention des Musées (Invention of Museums). Paris: Gallimard.

Skyten R. 2010. Historia. Societas Pro Fauna et Flora Fennica. http://www.societasfff.fi/seura/historia?lang=fi (1.11.2015)

Siitari P. 2012. Kiasma and the Guggenheim. Kiasma blog. Kiasma and the Guggenheim | Kiasma-blogi (Retrieved 1.5.2015)

Sokka, S., \& Kangas, A. (2007). At the Roots of Finnish Cultural Policy: Intellectuals, Nationalism, and the Arts. International Journal of Cultural Policy, 13 (2), 185-202.

Sokka, S. (2007). A Sociohistorical View of Cultural Policies. Nordisk kulturpolitisk tidskrift, 10 (2), 60-81.

SRGF. 2015. "Guggenheim Foundation." The Solomon R. Guggenheim Foundation (SRGF). http://www.guggenheim.org/guggenheim-foundation (Retrieved 1.8.2015)

Stankiewicz M.A. 2007. Capitalizing art education: mapping international histories. Bresler $\mathrm{L}$ Ed. International Handbook of Research in Arts Education. London: Springer.

Sullström H. 2012. YLE. Retrieved 6 April 2014.

Thaden E.C. 1981. Russification in the Baltic Provinces and Finland.

Triisberg A., Krikortz E., and Henriksson M. 2015. Art Workers, Material Conditions and Labor Struggles in Contemporary Art Practice. Tartu: Greif.

Uniarts. 2015. History of the Academy of Fine Arts, https://www.uniarts.fi/en/kuva/history (Retrieved 1.10.2015)

Volner I. 2015. "Can the Guggenheim charm Finland?" The New Yorker. http://www.newyorker.com/culture/culture-desk/can-the-guggenheim-charm-finland (Retrieved 1.9.2015)

Wainwright O. 2014. Helsinki vs. Guggenheim: the backlash against the global megabrand is on. The Guardian. 
Westerholm J. 2002. Populating Finland. Fennia 180: 1-2. Pp. 123-140. Helsinki: Fennia.

William K. Carr et al. 1974. Area Handbook for Finland.

Zablotney S. 1999. Original and Copy: the market of painting in the late eighteenth century London. Marchi N.D. and Goodwin C.D.W. Ed. Economic Engagements with Art. Duke University Press.

Zuck V. 2015. Finnish literature. Encyclopedia Britannica.

http://www.britannica.com/art/Finnish-literature (Retrieved 1.11.2015) 